\title{
Zika Virus Infection in Pregnant Women and Microcephaly*
}

\section{Infecção do vírus Zika em gestantes e microcefalia*}

\author{
Geraldo Duarte ${ }^{1}$ Antonio Fernandes Moron ${ }^{2}$ Artur Timerman ${ }^{3}$ César Eduardo Fernandes ${ }^{4}$ \\ Corintio Mariani Neto ${ }^{5}$ Gutemberg Leão de Almeida Filho ${ }^{6}$ Heron Werner Junior ${ }^{7}$ \\ Hilka Flavia Barra do Espírito Santo ${ }^{8}$ João Alfredo Piffero Steibel ${ }^{9}$ João Bortoletti Filho ${ }^{2}$ \\ Juvenal Barreto Borriello de Andrade ${ }^{10}$ Marcelo Burlá ${ }^{11}$ Marcos Felipe Silva de Sá ${ }^{1}$ \\ Newton Eduardo Busso ${ }^{12}$ Paulo César Giraldo ${ }^{13}$ Renato Augusto Moreira de Sá ${ }^{14}$ \\ Renato Passini Junior ${ }^{13}$ Rosiane Mattar ${ }^{2}$ Rossana Pulcineli Vieira Francisco ${ }^{15}$
}

1 Universidade de São Paulo, Ribeirão Preto, SP, Brazil

2 Universidade Federal de São Paulo, São Paulo, SP, Brazil

${ }^{3}$ Hospital Professor Edmundo Vasconcelos, São Paulo, SP, Brazil

${ }^{4}$ Faculdade de Medicina do ABC, Santo André, SP, Brazil

${ }^{5}$ Hospital Maternidade Leonor Mendes de Barros, São Paulo, SP, Brazil

${ }^{6}$ Universidade Federal do Rio de Janeiro, Rio de Janeiro, RJ, Brazil

${ }^{7}$ Alta Excelência Diagnóstica, Rio de Janeiro, RJ, Brazil

8 Universidade Federal do Amazonas, Manaus, AM, Brazil

${ }^{9}$ Pontifícia Universidade Católica, Porto Alegre, RS, Brazil,

${ }^{10}$ Consultório Médico Juvenal Barreto Borriello de Andrade, São Paulo, SP, Brazil
Address for correspondence Geraldo Duarte, Avenida Bandeirantes, 3900, 14049-900, Ribeirão Preto, SP, Brazil

(e-mail: gduarte@fmrp.usp.br).

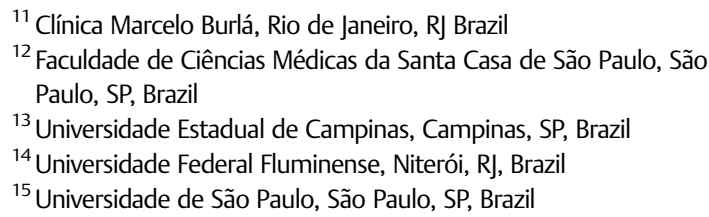

${ }^{11}$ Clínica Marcelo Burlá, Rio de Janeiro, RJ Brazil

Faculdade de Ciências Médicas da Santa Casa de São Paulo, São

${ }^{3}$ Universidade Estadual de Campinas, Campinas, SP, Brazil

${ }^{15}$ Universidade de São Paulo, São Paulo, SP, Brazil

Rev Bras Ginecol Obstet 2017;39:235-248.

\author{
Abstract \\ Keywords \\ - pregnancy \\ complications \\ - Zika virus \\ - arbovirus infections \\ - microcephaly/ \\ ultrasonography \\ - real-time polymerase \\ chain reaction \\ - deafness/ etiology \\ - blindness/ etiology
}

From the discovery of the Zika virus (ZIKV) in 1947 in Uganda (Africa), until its arrival in South America, it was not known that it would affect human reproductive life so severely. Today, damage to the central nervous system is known to be multiple, and microcephaly is considered the tip of the iceberg. Microcephaly actually represents the epilogue of this infection's devastating process on the central nervous system of embryos and fetuses. As a result of central nervous system aggression by the ZIKV, this infection brings the possibility of arthrogryposis, dysphagia, deafness and visual impairment. All of these changes of varying severity directly or indirectly compromise the future life of these children, and are already considered a congenital syndrome linked to the ZIKV. Diagnosis is one of the main difficulties in the approach of this infection. Considering the clinical part, it has manifestations common to infections by the dengue virus and the chikungunya fever, varying only in subjective intensities. The most frequent clinical variables are rash, febrile state, non-purulent
* This review is part of the Series, Guidelines and Recommendations of the Federação das Associações de Ginecologia e Obstetrícia - FEBRASGO, and it was prepared by the FEBRASGO National Provisional Specialized Commission for the Study of Zika Virus, Pregnancy and Microcephaly.

received

February 21, 2017

accepted

March 17, 2017
DOI https://doi.org/

$10.1055 / \mathrm{s}-0037-1603450$.

ISSN 0100-7203.
Copyright $\odot 2017$ by Thieme Revinter Publicações Ltda, Rio de Janeiro, Brazil
License terms

(®) $\Theta \circledast$ 
conjunctivitis and arthralgia, among others. In terms of laboratory resources, there are also limitations to the subsidiary diagnosis. Molecular biology tests are based on polymerase chain reaction (PCR) with reverse transcriptase (RT) action, since the ZIKV is a ribonucleic acid (RNA) virus. The RT-PCR shows serum or plasma positivity for a short period of time, no more than five days after the onset of the signs and symptoms. The ZIKV urine test is positive for a longer period, up to 14 days. There are still no reliable techniques for the serological diagnosis of this infection. If there are no complications (meningoencephalitis or Guillain-Barré syndrome), further examination is unnecessary to assess systemic impairment. However, evidence is needed to rule out other infections that also cause rashes, such as dengue, chikungunya, syphilis, toxoplasmosis, cytomegalovirus, rubella, and herpes. There is no specific antiviral therapy against ZIKV, and the therapeutic approach to infected pregnant women is limited to the use of antipyretics and analgesics. Anti-inflammatory drugs should be avoided until the diagnosis of dengue is discarded. There is no need to modify the schedule of prenatal visits for pregnant women infected by ZIKV, but it is necessary to guarantee three ultrasound examinations during pregnancy for low-risk pregnancies, and monthly for pregnant women with confirmed ZIKV infection. Vaginal delivery and natural breastfeeding are advised.

\section{Resumo}

\section{Palavras-chave}

- complicações na gravidez

- vírus da Zika

- infecções por arbovírus

- microcefalia/ ultrassonografia

- reação em cadeia da polimerase em tempo real

- surdez/ etiologia

- cegueira/ etiologia
Desde a descoberta do vírus Zika (VZIK) em 1947 em Uganda, na África, até sua chegada na América do Sul, não se tinha notícia de que ele seria capaz de comprometer a vida reprodutiva em humanos de forma tão severa. Hoje, sabe-se que os danos sobre o sistema nervoso central são múltiplos, e a microcefalia é considerada a ponta do iceberg, visto que na realidade ela representa o epílogo de um processo devastador desta infecção sobre o sistema nervoso central do embrião e do feto. Em decorrência da agressão do sistema nervoso central pelo VZIK, esta infecção pode provocar artrogripose, disfagia, surdez e comprometimento visual. Todas estas alterações, de gravidade variável, direta ou indiretamente comprometem a vida futura dessas crianças, já sendo considerada uma síndrome congênita ligada ao VZIK. Uma das principais dificuldades na abordagem dessa infecção é relativa ao diagnóstico. Considerando a parte clínica, observa-se que ela apresenta manifestações comuns às infecções pelos vírus da dengue e da febre chikungunya, variando apenas em suas intensidades subjetivas. As variáveis clínicas mais frequentes são o exantema, febrícula, conjuntivite não purulenta e artralgia. No tocante aos recursos laboratoriais, também existem limitações ao diagnóstico subsidiário. As provas de biologia molecular se fundamentam na reação em cadeia da polimerase (RCP) com ação da transcriptase reversa (TT), visto que o VZIK é um vírus ácido ribonucleico (ARN). A TRRCP apresenta positividade sérica ou plasmática por um período curto de tempo, não ultrapassando cinco dias após início dos sinais e sintomas. Esta pesquisa do VZIK na urina fica positiva por período mais prolongado, chegando a 14 dias. Ainda não existem técnicas seguras para diagnóstico sorológico dessa infecção. Não havendo complicações (meningoencefalite ou síndrome de Guillain-Barré), dificilmente são necessários mais exames complementares para avaliar o comprometimento sistêmico. No entanto, são necessárias provas para descartar as outras infecções que causam exantema, como dengue, chikungunya, sífilis, toxoplasmose, citomegalovírus, rubéola e herpes. Sabe-se que não existe terapia antiviral específica contra o VZIK, e a abordagem terapêutica de gestantes portadoras da infecção limita-se ao uso de antitérmicos e analgésicos. Orienta-se evitar anti-inflamatórios até que o diagnóstico de dengue seja descartado. Sobre a condução do pré-natal, não há necessidade de modificar o cronograma de consultas pré-natais para gestantes que foram infectadas pelo VZIK, mas é necessária a garantia de três exames ecográficos durante a gravidez para gestantes de baixo risco, e mensais para a gestante com infecção confirmada pelo VZIK. A via de parto é vaginal, e está liberado o aleitamento natural. 


\section{Introduction}

The dengue virus (DENV) has severely affected the Brazilian population for several decades, but there was no adequate social, political or sanitary response to deal with the vector control of this infection. The situation was not tackled with effective strategies, just like what occurred at the beginning of the last century for yellow fever control. This relative sanitary inertia, along with the constant adaptations of Aedes mosquitoes have made this insect a feared enemy able to dribble all timid interventions for its control, allowing the repetition of increasingly expanded epidemic peaks of arboviruses. In addition to these variables, globalization brought diseases with which the Brazilian population had not had prior contact, such as those caused by the Zika virus (ZIKV) and the chikungunya virus (CHIKV), which can be transmitted by humans or animals. However, attention with arboviruses was only raised in face of evidences of the association between the ZIKV and the occurrence of microcephaly. ${ }^{1-5}$ This fact has created a legitimate demand for the union of forces of professionals from all areas of health to care for people affected by this infection, whether mothers, their children or their families. ${ }^{6,7}$

Nowadays, there is no more questioning if ZIKV infection is responsible for embryonic, fetal and neonatal harm, but only if this diagnostic duality derives from a pure, accidental or incidental causal association. ${ }^{8}$ Nervous system diseases (embryonic, fetal and postnatal) resulting from ZIKV infection induced a considerable number of studies, pedagogical publications on the subject, and the creation of several care and surveillance protocols. ${ }^{9-16}$

Microcephaly resulting from ZIKV infection is the epilogue of a vast process of diffuse involvement of the embryonic/fetal nervous system that manifests clinically with the reduction of the cephalic perimeter. Over time, other abnormalities have been identified, such as deafness, visual deficiencies of varying degrees, dysphagia and arthrogryposis, resulting in a complex of alterations currently called 'congenital Zika virus syndrome'. As some of these changes occur in the postnatal period, the adequate care to mothers eventually affected by this infection should include guidance and the correct referral of 'all children exposed to this infection', not only those with organic birth defects. ${ }^{10}$

Nothing is definitive beyond the objective disposition to inform about the adequate care of mothers possibly affected by this infection and to provide the correct referral of the children eventually affected by this infection. This is a type of document that needs to be continuously re-evaluated and updated.

\section{Etiological Agent}

Considering the phylogenetic aspects, ZIKV is an arbovirus of the Flavivirus genus of the Flaviviridae family, transmitted by mosquitoes of the Aedes genus, among which Aedes aegypti is the most common in Brazil. Like other Flavivirus, its genome is composed of single-stranded ribonucleic acid (RNA) containing $1,0794 \mathrm{~Kb}$. It includes an open reading frame that encodes a polyprotein and two non-coding flanking regions in its replication process. Then, the polyprotein is cleaved in capsid (C) proteins, membrane precursor (Mpr), envelope (E), and in seven non-structural (NS) proteins called NS1, NS2a, NS2b, NS3, NS4a, NS4b and NS5. ${ }^{17,18}$ This high number of common cellular structures to all arboviruses explains the difficulty to elaborate diagnostic serological tests without cross-reactivity between one another.

\section{Particularities of ZIKV}

The initial description of the ZIKV occurred in 1947 in Uganda in a forest called Zika, and its isolation was found in sentinel rhesus monkeys of a yellow fever study. ${ }^{19}$ The first human case occurred in Nigeria in 1954, and its dispersion throughout the African continent was slow. Until 2007, the literature documents that the number of people affected by this virus did not exceed 50. After reports of sporadic cases in Asian countries, the first epidemic of this virus was observed in 2007 in Yap Island, located in the Pacific Ocean. ${ }^{20}$ In 2013, other epidemic peaks occurred in French Polynesia and Easter Island, and the virus finally arrived in Brazil between 2013 and 2014. The virus has undergone genomic recombination in this trajectory, and nowadays there are two lineages, one African and the other Asian, the latter responsible by the epidemic in Brazil. ${ }^{21,22}$ There is already information about other lineages, ${ }^{23}$ but officially, there are only two recognized lineages so far. These mutations seem to be responsible for the pathogenic profile that directly or indirectly associates the ZIKV with the occurrence of damage to the central nervous system of human fetuses. In this context, the significant increase of cases of Guillain-Barré syndrome and encephalitis in people affected by this infection is noteworthy. ${ }^{24}$ Several other alterations occurred, promoting an even greater adaptation of the ZIKV to Aedes genus mosquitoes. ${ }^{20}$ Reflecting on this vector premise, the spectrum of difficulties in this area seems to have potential to increase, and within the guidelines of attention to pregnant women, vector control strategies within the reach of patients, their families and the general community cannot be forgotten.

According to official information, the entry of ZIKV in Brazil seems to have occurred from states in the Northeast, and its dispersion coincides with an increased incidence of microcephaly cases in communities infested by Aedes aegypti. ${ }^{25}$

\section{ZIKV Transmission}

There is no doubt that the most important form of ZIKV transmission is through the bite of the Aedes genus mosquito, the same transmitter of DENV and CHIKV, among others. ${ }^{26}$ Therefore, the combat of the mosquitoes and their proliferation is considered the only truly effective intervention to control these diseases so far.

Concerning the unparalleled importance of the vector transmission of the ZIKV infection, from the perspective of gynecologists and obstetricians there are additional concerns regarding the vertical and sexual transmission of the ZIKV. Considering the vertical transmission, the risk of ZIKV congenital infection syndrome dominates the scenario of seizures (brain damage resulting in microcephaly, arthrogryposis, 
dysphagia, severe auditory and ocular alterations, among others). ${ }^{27-29}$ The growing fear after confirmation of ZIKV sexual transmission forced the world's leading health agencies to develop care protocols that are constantly modified by additional knowledge on the subject. ${ }^{30,31}$ This fact has brought objective difficulties for couples who planned their pregnancies for current times, either naturally or with assisted reproduction resources. The sexual transmission of the ZIKV has been determined to occur from men (symptomatic and asymptomatic) to women, from symptomatic women to men, and in penis-anus relationships between men. ${ }^{32}$

The presence of the ZIKV has also been confirmed in urine, breast milk, tears and saliva, but it is not yet possible to qualify these fluids as 'effective vehicles' in the transmission of the infection. ${ }^{33}$ Despite the presence of the virus in breast milk, the general orientation is not to discontinue breastfeeding in cases of puerperal women infected with the ZIKV. ${ }^{6,7,11}$ Although rare, transmission by blood transfusion and organ transplantation has also been reported on some occasions. $^{34-36}$

Despite knowledge advances on ZIKV infection, to date there is no reliable information on whether the immunity conferred by the natural virus infection is permanent and can prevent new infections. However, the greater concern regards the previous circulation of this virus only in some regions of Brazil, making most of the population still susceptible to this infection and without any type of immunity against it. Even after the first epidemic peak in the summer of $2015 / 2016$, a large number of pregnant women are still expected to become infected in the summer of 2016/2017 in Brazil, because the exhaustion of those susceptible to this infection has not yet been observed.

\section{Diagnosis of ZIKV Infection}

Clinical diagnosis is initially considered to diagnose ZIKV infection, remembering the limitations resulting from the asymptomatic form of the infection. ${ }^{37,38}$ The epidemiological diagnosis complements the clinical diagnosis, with the aim of clarifying the pregnant woman's trajectory in terms of trips and contact with sick people, or who have visited high endemic areas.

\section{Clinical Diagnosis of ZIKV Infection}

In most cases, ZIKV infection is a clinically self-limiting disease, but still considered an acute febrile illness. Since the beginning of the spread of the virus in Brazil, experts have observed the disease pattern of low fever (lower than $38.5^{\circ} \mathrm{C}$ ) or no fever, lasting 1 to 2 days, accompanied by a pruritic and coarse rash of variable duration (2 to 7 days), mild muscle pain, joint pain and joint edema of mild to moderate intensity. Non-purulent conjunctivitis is observed in most cases. ${ }^{39}$

In Brazil, the main differential diagnoses of ZIKV infection are the other arboviruses caused by DENV and CHIKV. - Table 1 shows a summary of the clinical manifestations of these three diseases based on their diagnosis. In

Table 1 Frequency and comparative intensity of the most common signs and symptoms in ZIKV, DENV and CHIKV infections

\begin{tabular}{|c|c|c|c|}
\hline Signs/Symptoms & DENV & ZIKV & CHIKV \\
\hline Fever (duration) & $\begin{array}{l}\text { Above } 38^{\circ} \mathrm{C} \\
\text { ( } 4 \text { to } 7 \text { days) }\end{array}$ & $\begin{array}{l}\text { No fever or subfeb- } \\
\text { rile } \leq 38^{\circ} \mathrm{C}(1-2 \\
\text { days subfebrile })\end{array}$ & $\begin{array}{l}\text { High fever }>38^{\circ} \mathrm{C} \\
(2-3 \text { days })\end{array}$ \\
\hline Rash (frequency) & $\begin{array}{l}\text { Appears from the } \\
4^{\mathrm{th}} \text { day in } 30-50 \% \\
\text { of cases }\end{array}$ & $\begin{array}{l}\text { Appears on } 1^{\text {st }} \text { or } \\
2^{\text {nd }} \text { day in } \\
90-100 \% \text { of cases }\end{array}$ & $\begin{array}{l}\text { Appears in } 2-5 \text { days } \\
\text { in } 50 \% \text { of cases }\end{array}$ \\
\hline Muscle pain (frequency) & $+++1+++$ & $++1+++$ & $+1+++$ \\
\hline Joint pain (frequency) & $+1+++$ & $++1+++$ & $+++1+++$ \\
\hline Intensity of joint pain & Mild & Mild/Moderate & Moderate/Intense \\
\hline Joint edema & Rare & $\begin{array}{l}\text { Frequent and mild } \\
\text { intensity }\end{array}$ & Frequent and from moderate to intense \\
\hline Conjunctivitis & Rare & $50-90 \%$ of cases & $30 \%$ \\
\hline Headache (Frequency and intensity) & +++ & ++ & ++ \\
\hline Itching & Mild & Moderate/Intense & Mild \\
\hline $\begin{array}{l}\text { Lymph node hypertrophy } \\
\text { (frequency) }\end{array}$ & Mild & Intense & Moderate \\
\hline $\begin{array}{l}\text { Hemorrhagic dysrhythmia } \\
\text { (frequency) }\end{array}$ & Moderate & Absent & Mild \\
\hline Neurological impairment & Rare & $\begin{array}{l}\text { More frequent than } \\
\text { DENV and CHIKV }\end{array}$ & Rare (predominant in newborns) \\
\hline
\end{tabular}

Abbreviations: CHIKV, chikungunya virus; DENV, dengue virus; ZIKV, zika virus.

Note: Modified from Duffy et al, ${ }^{38}$ Brito C. (updated in December/2015 by the Ministry of Health). ${ }^{11}$ 
ZIKV infection, the exanthematic picture is very marked, with conjunctival hyperemia, but without significant alteration in joint involvement. In general, the symptoms disappear in three to seven days after their onset. ${ }^{38,39}$ During the anamnesis, it is important to obtain information about the general causes of the rash, such as exogenous intoxications, allergies to medicines or allergenic substances. These responses are only possible if objectively surveyed, and must be in the differential diagnosis of arboviral infections. Even considering the rarity, eventual clinical manifestations of toxoplasmosis, syphilis, herpes, rubella and cytomegalovirus are also part of this information. ${ }^{10,12}$

\section{Epidemiological Diagnosis}

The clinical diagnosis can be enriched with epidemiological information of fundamental importance in the differential diagnosis of rheumatic causes. The following information is particularly important: about the contact with people diagnosed as having DENV, CHIKV and/or ZIKV infections; contact with people with other exanthematous diseases; use of medication/alcohol/illicit drugs during pregnancy; and residence or travel to areas of ZIKV infestation during pregnancy. ${ }^{6,38}$

The high frequency of rashes in symptomatic cases of ZIKV infection was the main factor that made it a clinical marker to include pregnant women in the diagnostic flows of this infection. In the presence of this signal, the pregnant woman should notified the Municipal Epidemiological Sur- veillance (ES) that informs the reference Epidemiological Surveillance Group (ESG), after completing the ES specific form. ${ }^{7,12}$ With these measures, it is expected that at least the symptomatic cases will be notified ( - Fig. 1). This important step should include the help from ES professionals of the basic network, hospitals and municipalities for the completion of these forms.

\section{Laboratory Diagnosis of ZIKV Infection}

To confirm the clinical and epidemiological suspicion of ZIKV infection, three blood samples should be requested. The first sample is used to identify NS-1 (differential diagnosis with DENV); the second sample evaluates the differential diagnoses with syphilis, toxoplasmosis, rubella, type 2 herpes and cytomegalovirus (to request these exams, one should consider if the pregnant woman already has these serologies indicating previous contact with the etiological agents, if she has proof of vaccine against rubella, and the availability of these tests in the particular community); and the third sample is used to confirm the presence of ZIKV RNA. If there is no absolute certainty that the maternal rash is clearly derived from exogenous intoxications, the use of medications or other non-infectious causes, performing these tests is recommended. In practice, all pregnant women with a rash should undergo these exams.

It is just a matter of time before the performance of all of the previously mentioned exams becomes mandatory. When a specific and safe serological test for immunoglobulin $M$

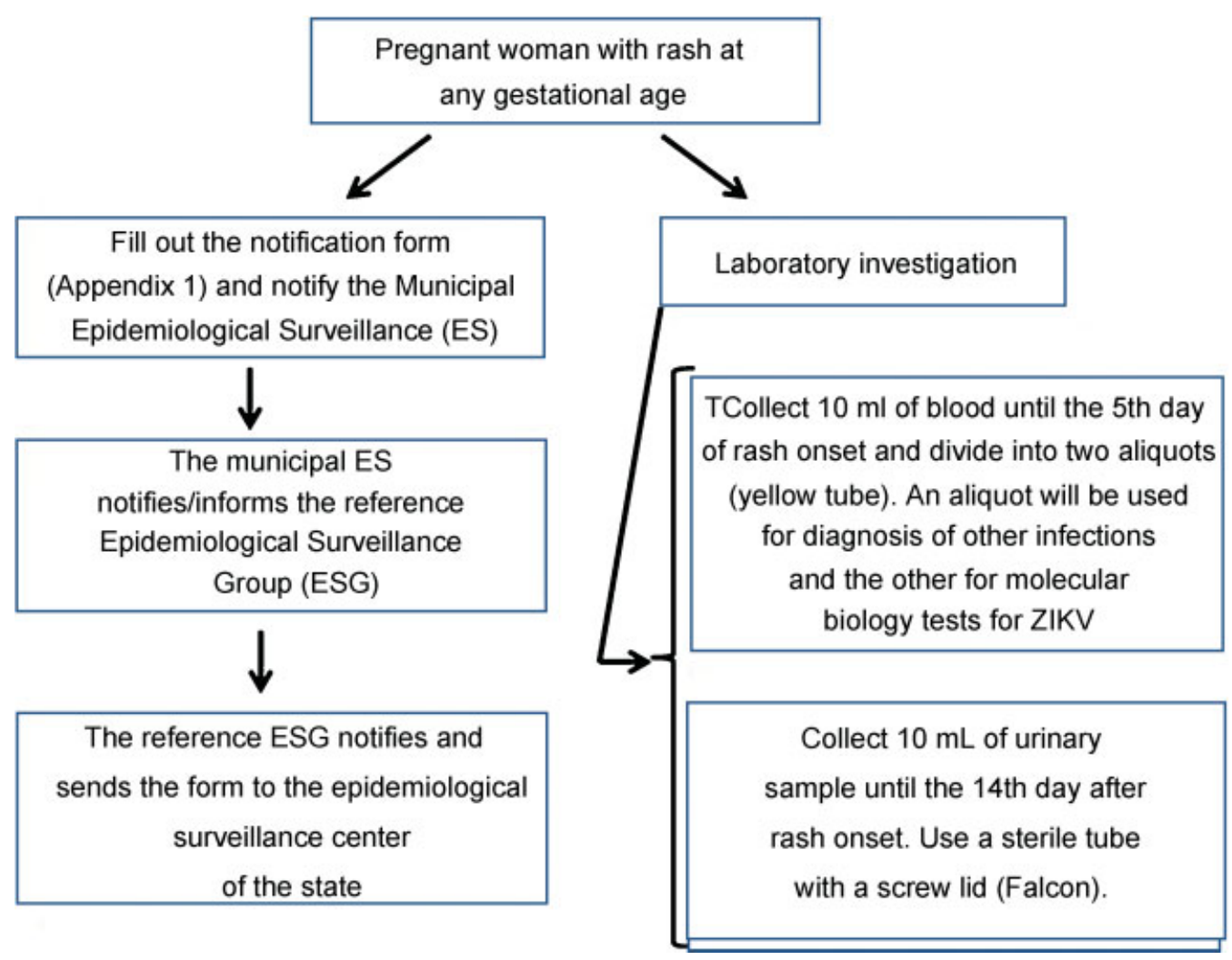

Fig. 1 Flowchart to guide diagnostic and health surveillance actions in the care of pregnant women with rashes. 
(IgM) dosing against ZIKV is possible, it may not be necessary to request the serologies that make differential diagnosis between the diseases causing syphilis, toxoplasmosis, rubella, cytomegalovirus and herpes (STORCH) syndrome, currently called Z-STORCH. ${ }^{10}$ In spite of all promises of the Brazilian Official Health Offices about the existence of accurate diagnostic tests for ZIKV infection (rapid tests), in practice, they are not available for the Brazilian Unified Healthcare System (SUS, in the Portuguese acronym).

To date, for confirmation of ZIKV infection in pregnant women with a rash, the preferred screening test is the reverse transcriptase polymerase chain reaction (RT-PCR) of ZIKV RNA. Given the short duration of the viremic period, viral RNA detection is possible only for a seven-day period after the onset of the symptoms. However, aiming for greater effectiveness of the technique, it is recommended to examine the material by the fifth day after the onset of the clinical manifestations. For urine RT-PCR, the period is a little longer, up to the 14th day after the onset of the symptoms with commercially available exams. ${ }^{40}$

At the request of the Centers for Disease Control and Prevention (CDC), in September 2016, the Food and Drug Administration (FDA) of the United States released the Trioplex Real-time RT-PCR Assay for use in emergencies such as ZIKV infection during pregnancy. This RT-PCR evaluates the presence of DENV, CHIKV and ZIKV in a single sample, in a single test. However, this test has not yet been released for commercialization in Brazil. ${ }^{41}$

The serological tests commercially available in Brazil have low specificity for detection of ZIKV-specific antibodies. Cross-reactivity with infections caused by other arboviruses (DENV, CHIKV and yellow fever virus, among others) absurdly increases costs, and results in diagnosis of ZIKV infection by exclusion, making the diagnostic process financially unaffordable. At present, the method for large-scale antibody titration recommended by the Brazilian Ministry of Health is based on in-house Enzyme-Linked Immunosorbent Assay (ELISA) techniques, a protocol established by the CDC (CDC, 2016). ${ }^{42}$ This test is already standardized in some state-run laboratories in Brazil, but with limited availability to the public. It would primarily serve pregnant women with a history of exanthematous disease, although outside the ideal collection period for the RT-PCR test for ZIKV, or those with present diagnosis of fetal microcephaly during pregnancy and without previous diagnosis of ZIKV infection. However, laboratories cannot even meet the demand for these specific groups. In summary, in practice, we do not yet have a serological test available for our SUS population.

From what is known to date, there is no need to change the laboratory routine of each prenatal service (each municipality has its prenatal laboratory priorities). The need to include any other test in the list of routine laboratory exams for prenatal care is still unknown. ${ }^{10}$

\section{Diagnosis of Systemic Involvement}

Although characterized as atypical and rare, severe forms of ZIKV infection in pregnant women have been described, such as extreme dehydration, severe joint involvement, encephalitis and Guillain-Barré syndrome. ${ }^{43}$ These forms can be so severe they can cause death in both adults and fetuses. 6,24,27 In these cases, the help of professionals connected to neurology and advanced life support is imperative.

If there is a clinical indication to evaluate the systemic compromise in cases of pregnant women with suspected ZIKV infection, the most commonly used tests are those measuring the body's response to the infection. However, there is no laboratory specificity for this evaluation resulting from ZIKV infection; hence, the definition of which tests to request will depend on the organic system affected and the health professional's decision, including the decision of the need for tests. In general, the hemogram may indicate moderate leukopenia and thrombocytopenia, but it may also assist in differentiating viral infection from bacterial infection. A more pronounced reduction in platelet count would indicate bleeding risk and a greater likelihood of DENV infection. In turn, the assessment of the hepatic function in ZIKV infection will identify a slight or no elevation of enzymes, bilirubin, and markers of inflammatory activity. Depending on the degree of systemic involvement, renal function may indicate a slight elevation of urea, creatinine, and sodium and potassium changes. ${ }^{6,11,39}$ One should note that these changes are rare in ZIKV infection.

\section{Prophylaxis of the Aedes Aegypti Bite}

Vector control is surely the most important prophylactic measure to avoid ZIKV infection. Preventing the Aedes aegypti mosquitoes' reproduction would be the most logical measure to be adopted; however, considering Brazil as a whole, the attempts to do so have been unsuccessful so far. As the flight range of the Aedes mosquito is $\sim 50 \mathrm{~m}$, it is important to try to control outbreaks and breeding places in this radius of distance, ${ }^{44}$ since this is possible in some communities and could serve as an example to others.

When control of the vector breeding sites fails, people should be careful and try to avoid contact with the mosquito. The strategies to prevent infection include avoiding the same environment of people with suspected ZIKV infection, and avoiding trips to areas of high incidence of the disease. In this group of interventions, preventing mosquitoes from entering homes by using window screens in single-story houses or in buildings near high areas that harbor Aedes outbreaks may aid in prophylaxis.

Some details about the mosquitoes' habits and measures to avoid their bites are noteworthy. ${ }^{39}$ As it flies low $(\sim 1.5 \mathrm{~m})$, the protection of feet and legs with long pants, socks, closed shoes and long-sleeved shirts/sweaters is essential, reducing to the maximum the area of exposed skin. The use of light colored clothing is also advised, because the mosquito is attracted by dark clothes. It flies with greater agility at temperatures above $28^{\circ} \mathrm{C}$, and practically does not move without stimulus at temperatures below $18^{\circ} \mathrm{C}$. Its preferred flying time is between 9 a.m. and 4 p.m., the period of the day in which sunlight is at its brightest. ${ }^{44}$ The places with greater number of Aedes mosquitoes are those with high luminosity, 
without basic sanitation, and with inefficient garbage collection.

Prophylaxis measures against Aedes aegypti bites are completed with the use of repellent in any exposed area of the skin. When wearing wide woven fabric clothing, the repellent should be used underneath the fabric, as there are doubts about its actual effectiveness when used over the fabric. The most suitable repellents for use in pregnant women are those containing icaridin, N,N-diethyl-3-methylbenzamide (DEET) and ethyl 3-[acetyl(butyl)amino]propanoate (IR3535). ${ }^{16}$ In communities with higher temperatures, these repellents should be reapplied in shorter periods than recommended. Care should be taken to avoid contact of these compounds with the eyes, mouth and nose. The intake of thiamine and B1complex vitamins is not proven to be effective as a repellent, and its indication of use is not approved by the Brazilian National Sanitary Surveillance Agency (Anvisa, in the Portuguese acronym).

\section{Microcephaly and ZIKV Infection}

According to information from the Brazilian Center for Emergency Operations in Public Health on Microcephaly, up to epidemiological week 52 ( 25 to $31 / 12 / 2016$ ), of 10,867 reported cases of microcephaly, 2,366 had already been confirmed as having infectious etiologies, with a high probability that the ZIKV was the cause of those etiologies. The remaining cases have been discarded or are still under investigation. $^{45}$

\section{Concept and Prognosis of Microcephaly}

From the conceptual point of view, microcephaly represents a disruption of the neurological development causing the cephalic perimeter (CP) measurement of the fetus or newborn to be two standard deviations (SDs) below the normality limit for gestational age and sex. ${ }^{46,47}$ Some authors and services also consider percentiles, observing that two SDs would correspond to percentile three. ${ }^{48,49}$

Regarding prognosis, mild microcephaly is when the CP measurement is between two to three SDs below the mean for age and sex (fetal or neonatal), and severe microcephaly is when the CP measurement is below three SDs. ${ }^{11,50}$ In general, the more severe and stronger the microcephaly, the more compromised is the prognosis. ${ }^{51}$ In severe microcephaly, in rare cases the neuropsychomotor development does not confirm this association. However, it is difficult to predict the prognosis in mild microcephaly. ${ }^{52}$

The central nervous system begins its differentiation early, but there is risk of some impairment even after the end of pregnancy. Disruptive alterations due to ZIKV infection occur less frequently in the final trimesters of pregnancy, but little is known about functional changes. As is known, myelination processes continue after birth. Studies have demonstrated the potential of the ZIKV to invade and destroy nerve cells in experimental models, which may explain the role of this virus in the genesis of microcephaly. ${ }^{53}$ According to Honein et $\mathrm{al}^{54}$ the rate of any organic change in fetuses of
ZIKV-infected mothers during pregnancy is of $6 \%$. However, if the infection occurred during the first trimester, this rate can reach $11 \%$, because it occurs in a phase of high potential of cellular differentiation. ${ }^{55}$ In the city of Ribeirão Preto, Brazil, the rate of severe fetal involvement in mothers with symptomatic ZIKV infection is of $6.2 \%$.

According to Oliveira Melo et al, ${ }^{56}$ microcephaly associated with ZIKV would be just the tip of the iceberg. Only the evolution of the knowledge on the subject enabled the confirmation of additional harm to the perinatal health of these children resulting from this infection, such as severe ocular involvement, deafness, diffuse damage in the central nervous system, arthrogryposis and severe dysphagia. 9,28,29 For Suy et $\mathrm{al}^{57}$ the evidence indicates that cases of vertical transmission and severe fetal impairment are linked to a longer period of maternal ZIKV viremia.

\section{Causes of Microcephaly}

Some authors consider the etiological factor to qualify microcephaly as a malformation or disruptive injury. Malformation is considered when the cause is genetic (intrinsic), and disruptive injury, when the cause is extrinsic, like infections. ${ }^{37}$ It is important to remember that the presence of an etiological factor of microcephaly, like maternal infection by the ZIKV, does not make the risk of this harm to the fetus or newborn mandatory. - Table $\mathbf{2}$ is a summary of the most frequent causes among the more than 500 known causes of microcephaly. ${ }^{52,58,59}$

\section{Reference Curves for the Diagnosis of Fetal Microcephaly}

The entire diagnostic expectation of fetal microcephaly rests on the ultrasound examination, both for the obstetrician and the parents. Given this high anxiety situation of the family related to the severity of the diagnosis, sonographers seek the most reliable parameters, so that the exam result is the closest to biological reality.

The measurements of CP normality depend on gestational age and sex, and there is no way to correctly diagnose microcephaly (deviation from normality) without the exact dating of the pregnancy, which can be obtained with the date of the last menstrual period and the first trimester echocardiogram. In this period, in experienced hands, the margin of error of the ultrasonography evaluating the embryonic crown-rump length is minimum, and does not exceed three days. ${ }^{51}$ In more advanced pregnancies and when the patient does not know the last menstrual period date, the ultrasonography is still a good resource to approximate gestational age, but with reduced effectiveness. In this situation, without the last menstrual period date, a good alternative is to combine the measurements of the $\mathrm{CP}$ with the fetal length, which can improve the ultrasound results. ${ }^{60}$

Undoubtedly, the technical ability to correctly obtain the CP measurement is fundamental, but there must be consistency in diagnostic standards ${ }^{61}$ and in the reference curves of cranial growth. Among the various reference curves to qualify 
Table 2 Most frequent causes of microcephaly (congenital and postnatal)

\begin{tabular}{|c|c|}
\hline CONGENITAL & POSTNATAL \\
\hline $\begin{array}{l}\text { Chromosome and/or genetics } \\
\text { Trisomies of } 13,18 \text { and } 21 \\
\text { Cornelia de Lange syndrome } \\
\text { Cri du Chat syndrome } \\
\text { Smith-Lemli-Opitz syndrome }\end{array}$ & $\begin{array}{l}\text { Chromosome and/or genetics } \\
\text { Inborn errors of metabolism } \\
\text { Mitochondrial diseases } \\
\text { Aminoacidopathies } \\
\text { Defects in glucose transport }\end{array}$ \\
\hline AQUIRED & AQUIRED \\
\hline $\begin{array}{l}\text { Disruptive traumas } \\
\text { Hypoxia or anoxia (insufficient placenta) } \\
\text { Death of a twin (monochorionic) }\end{array}$ & $\begin{array}{l}\text { Disruptive traumas } \\
\text { Traumatic brain injury } \\
\text { Parenchymal hemorrhage (more common in preterm children) } \\
\text { Hypoxia or anoxia }\end{array}$ \\
\hline $\begin{array}{l}\text { Infections and protozooses } \\
\text { Syphilis } \\
\text { Toxoplasmosis } \\
\text { Rubella } \\
\text { Cytomegalovirus } \\
\text { Herpes simplex } \\
\text { Parvovirus B19 } \\
\text { Zika virus } \\
\text { Other viruses }\end{array}$ & $\begin{array}{l}\text { Infections } \\
\text { Meningitis } \\
\text { Encephalitis }\end{array}$ \\
\hline $\begin{array}{l}\text { Teratogens/clinical conditions } \\
\text { Alcohol } \\
\text { Hydantoin } \\
\text { Drugs (cocaine, crack, among others) } \\
\text { Radiation } \\
\text { Maternal diabetes mellitus without adequate control } \\
\text { Maternal phenylketonuria }\end{array}$ & $\begin{array}{l}\text { Toxins } \\
\text { Copper poisoning } \\
\text { Chronic renal failure }\end{array}$ \\
\hline $\begin{array}{l}\text { Deprivation } \\
\text { Maternal hypothyroidism } \\
\text { Folic acid insufficiency } \\
\text { Malnutrition } \\
\text { Insufficient placenta }\end{array}$ & $\begin{array}{l}\text { Deprivation } \\
\text { Hypothyroidism } \\
\text { Malnutrition } \\
\text { Anemia } \\
\text { Congenital cardiopathy }\end{array}$ \\
\hline
\end{tabular}

Note: Adapted and modified from Ashwal et al., ${ }^{52}$ Abuelo. ${ }^{58}$

(directly or indirectly) the growth of the $\mathrm{CP}$ throughout pregnancy, ${ }^{62-64}$ several representative colegiates of health in the country ${ }^{11}$ and worldwide ${ }^{15}$ choose to use the curves of Intergrowth $21 .^{47,48}$ All existing curves have pros and cons that limit or stimulate their adoption in a systematic way and as a protocol. For the situation in question, those with more positive factors were the curves of Intergrowth $21 .^{49}$ This is a reference curve for cranial circumference growth. It is easy to use and fairly representative, since it was elaborated with samples from several countries, including Brazilian children, and contemplates the evaluation of preterm fetuses.

Reference measurements of fetal cranial circumference of extreme preterm, preterm, and full-term fetuses, considering fetal gender, can be found at: https://intergrowth21.tghn. org/articles/intergrowth-21st-fetal-growth-standards/

The files in this website are in Excel (Microsoft, Redmond, WA, US) spreadsheets, and can be easily accessed, including the calculator that allows the remote calculation of microcephaly by introducing the fetal anatomical variables (weight, femoral length, cranial circumference). Check http://intergrowth21.ndog.ox.ac.uk/pt/ManualEntry

The results obtained can be in percentiles or SD ( $Z$ score). In fact, they inform in which SD is the cranial circumference in relation to the expected standard for that specific gestational age. Results in percentiles can be found at: https://intergrowth21.tghn.org/site_media/ media/articles/INTERGROWTH21st_Fetal_charts_Head_ Circumfrance_11062015.pdf

Following the intrauterine pattern of fetal circumference, the same principles guided the choice for reference standards to diagnose microcephaly after birth. The curves of Intergrowth $21,{ }^{65}$ elaborated to evaluate preterm and full-term infants in the postnatal period, were then used once more.

\section{Ultrasound Screening of Fetal Microcephaly}

For microcephaly screening during low-risk prenatal care, the minimum ultrasound protocol during pregnancy should consider at least three exams. The first examination should be performed around the 12th week of pregnancy (10-14 weeks); the second (morphological) should be performed around the 22nd week (18-24 weeks); and the third should be performed around the 32nd week (28-34 weeks). Obviously, other ultrasound examinations may be requested, but there is no added value without a precise indication to justify it. 
In trying to screen the damage to the fetus' central nervous system, the objective of all ultrasound examinations is to identify as early as possible the suggestive markers of injury associated with ZIKV infection. ${ }^{57}$ These include the reduction of the cephalic circumference, dilation of the cerebral ventricles, parenchymal, periventricular or basal nuclei calcifications, porencephaly or destructive injuries (mainly in the posterior fossa), enlargement of the subarachnoid space, and arthrogryposis. Among the non-specific signs that may occur during ZIKV infection in pregnant women, the following stand out: restriction of fetal growth (mainly after 32 weeks), oligohydramnios, placental calcifications, and fetal death. If the ultrasound examination detects any of these abnormalities in pregnant women with no clinical suspicion of ZIKV infection (which may be due to an asymptomatic infection), it is necessary to assess the fetal damage and seek the differential diagnosis of the cause.

When detecting alterations in the fetus' central nervous system, if possible, the pregnant woman should be referred to services with greater potential of care resources. The image examination should be complemented by magnetic resonance imaging (MRI $)^{61}$ in an attempt to diagnose alterations difficult to evaluate by ultrasound, such as encephalomalacia, real ventriculomegaly dimension, cortical atrophy, cerebellar hemisphere hypoplasia and brain stem atrophy, among others.

For pregnant women diagnosed with ZIKV infection, the ultrasound exam is performed monthly. Similarly, if fetal abnormality is detected, the pregnant woman should be referred to services with better resources and have her image examination complemented by an MRI.

\section{Pre-gestational Conduct}

Confirmation of the sexual transmission of the ZIKV has brought additional concerns to gynecologists/obstetricians. This fact has brought objective difficulties to couples who have planned pregnancies for the present time, both naturally or using assisted reproduction resources. It has also challenged the main health agencies in the world to develop care protocols that are constantly updated as a result of additional knowledge on the subject. ${ }^{11,30,31}$

As ZIKV can be transmitted through sexual activity, it is essential to anticipate reproductive care for the preconceptional period. Therefore, women should be oriented about the risks of becoming pregnant without planning, emphasizing the use of an effective contraceptive method in times of ZIKV infection by avoiding pregnancy without planning for proper gestational care. ${ }^{66}$ According to Atkinson et al, ${ }^{67} 53 \%$ of men with symptomatic ZIKV infection have seminal virus elimination.

From a practical point of view, McCarthy ${ }^{68}$ suggests it seems logic that prospective mothers at risk of ZIKV infection should postpone the pregnancy project, wait for the end of the turmoil caused by the ZIKV infection epidemic, and for the discovery of ways to effectively prevent the vertical transmission of the virus. ${ }^{69}$ However, there is a great misconception about the meaning and effectiveness of guidelines radically against the couple's decision to get pregnant. In general, those able to plan the pregnancy have a clear idea of the risk of ZIKV infection. Depending on their life moment, such as the limit of reproductive life, they will accept the ability to avoid the risk of infection regardless of contraindications to pregnancy at this time. In these cases, when taking the risk, it is crucial that the couple is very well advised on how to avoid the infection.

In addition to the general guidelines for ZIKV vector control (creating physical barriers), and to avoid the bite of the mosquitoes (with the use of repellents and clothes that protect the skin to the maximum extent possible), men who had the infection or have been in an area of high endemicity are advised to use a condom for six months from the infectious event, or to return from the area of greater risk, because there has been documentation of viral elimination in semen for 92 days, ${ }^{70}$ motivating the current orientation of 180 days of protected sex after the partner's infection. However, this orientation may change because Barzon et $\mathrm{al}^{71}$ have found seminal elimination of the virus until 181 days after the infection. Similar findings have been described by Atkinson et al, ${ }^{68}$ who state this phenomenon may last up to six months after a symptomatic ZIKV infection.

In case the partner of a man who had ZIKV infection chooses pregnancy, the use of condoms becomes imperative in the gestational period. If the woman has been infected by the ZIKV, she is requested not to become pregnant for 60 days, until new evidence can establish this period with greater accuracy.

International reports indicate that up to $80 \%$ of ZIKV infections may be asymptomatic, ${ }^{38}$ which would logically place all our women at potential risk of becoming sexually infected in our day and age. In this case, the great challenge is not to allow pregnant women to be exposed to the risk of becoming infected by the ZIKV eventually conveyed by their partners' semen. In addition, the couple should be objectively oriented and informed (in writing, obligatorily) of the limits of laboratory techniques in the diagnosis of asymptomatic infections caused by this virus. However, based on Anvisa guidelines, ${ }^{72}$ the couple should only be considered fit for an assisted fertilization procedure when serum tests indicate no acute infection, represented by the presence of $\operatorname{IgM}$, using the tests available in Brazil.

\section{Conduct for Pregnant Women}

Considering ZIKV infection, there should be strategies for four different groups of pregnant women. The first group comprises pregnant women with no manifestation related to ZIKV infection (low-risk prenatal care). The second is formed by pregnant women with rashes; the third includes pregnant women with confirmed ZIKV infections; and the fourth includes pregnant women whose fetuses had some complication compatible with infection by this arbovirus (among which microcephaly). Each of these scenarios will be discussed separately. 


\section{Prenatal Care for Pregnant Women with No Previous History of ZIKV Infection and No Clinical Manifestations}

According to the current knowledge about ZIKV infection in pregnant women, the strategy for this group prioritizes prophylaxis, providing guidance on self-protection against the mosquito. To this end, there should be orientation on barrier measures (door and window screens, mosquito nets with thin fabrics on beds), clothing that protects as much body surface as possible, and the use of repellents. ${ }^{16}$ The most indicated are those containing icaridin, DEET or IR3535. Care should be taken to avoid contact with the eyes, mouth and nose. We must recall that ingestion of sweat-excreted $B$ complex compounds (vitamin B1) has no proven efficacy as a repellent.

After confirming the sexual transmission of the ZIKV and knowing that a large part of people who acquire the infection are asymptomatic, there should be guidance on sexual abstinence or imperative use of condoms if the partner has symptoms suggestive of ZIKV infection or a confirmed disease. ${ }^{73}$ In these cases, authors as Oster et $\mathrm{al}^{30}{ }^{30}$ and Citil-Dogan et $\mathrm{al}^{74}$ are radical, and recommend the use of condoms until the end of pregnancy, because the duration of ZIKV elimination through the semen is not known exactly. Having traveled to regions of higher prevalence of infection in Brazil loses importance a little, but should still be considered, since there are regions where ZIKV infection has not been detected.

If serological tests were available to diagnose possible asymptomatic infections by the ZIKV during prenatal care, they could be used with the strict objective of providing differentiated prenatal care. It would not be appropriate to screen pregnant women simply to know if they have had the infection previously, also because it is not known if a prior infection represents immunization for the rest of life. Another risk of universal and non-objective serological screening is the potential lack of attention and neglect to avoid infection by other arboviruses in case of confirmation of previous infection by the ZIKV. Although so far they do not have any association with fetal malformations, both CHIKV and DENV infections have compromised gestational and perinatal prognoses. It is important to remember that the vertical transmission rate of CHIKV varies from 27.5 to $48.3 \%$, with a neonatal mortality rate of $5.1 \% .{ }^{74}$ In turn, maternal infection by DENV causes a miscarriage rate 3.3 times higher than that observed among pregnant women in control groups. ${ }^{75}$

To date, there is no justification to change the set of routine laboratory exams for prenatal care used in the prenatal care community. The prenatal consultation interval (return consultations) and vaccination schedule are also not modified. However, at least three obstetrical ultrasound examinations are guaranteed for pregnant women. The first is around the 12th week of pregnancy (between 10 and 14 weeks, very important for gestational dating); the second is morphological, and performed around the 22nd week (between 18 and 24 weeks); and the third is performed around the 32nd week (between 28 to 34 weeks). Obviously, other ultrasound exams may be required in case of other specific indications.

For the group of asymptomatic pregnant women at the moment, but who mention previous clinical manifestations compatible with prior ZIKV infection during pregnancy, there must be orientation regarding care to avoid mosquito bites, as it is not certain if the infection was really by the ZIKV. These pregnant women should maintain the same care as asymptomatic pregnant women, that is, 'absolute priority to prophylaxis, providing guidance on how to protect themselves against the mosquito'. 'The imperative use of condoms if the partner has symptoms suggestive of ZIKA/confirmed disease, or sexual abstinence' is also advised. For the laboratory diagnosis of these pregnant women, there is the limitation imposed by the RT-PCR diagnosis (until the 5th day in the blood and up to 14th day in the urine). This laboratory resource will have little chance of assisting in the diagnosis. The use of currently available serological tests is also limited because there is no determination of their positive or negative predictive values. In summary, the care for these women would be based solely on ultrasound examinations and regular prenatal care, without changes in the calendar of appointments (return consultations), complementary exams and vaccination schedule. If fetal changes are detected, the patient moves to high-risk prenatal care. For delivery, the obstetric orientation is maintained for these pregnant women, without indication of cesarean delivery. ${ }^{10}$ In the puerperal period there are no changes either, including natural breastfeeding.

\section{Care to Pregnant Women with Clinical Manifestation of ZIKV Infection}

Considering the current slow speed in the large-scale diagnosis of ZIKV infection, ${ }^{10}$ and the possibility that up to $80 \%$ of infections may be asymptomatic, a clinical marker of the infection for the entry of pregnant women into diagnostic and care flows was adopted. Rash is the most prevalent among these markers, hence the reason for its choice. To normalize the care flow, the initial approach of all pregnant women should be in the health units within their communities, where exams will be collected and sent to the previously established reference laboratories.

Regardless of where and how will the prenatal care of pregnant women with ZIKV infection be provided, provision of care and psychological support to these women and their families is essential. ${ }^{10}$

\section{Clinical and Laboratory Diagnosis of ZIKV Infection}

The resources of anamnesis, physical examination and epidemiological information are used to diagnose ZIKV infection. In the clinical diagnosis, low fever, non-purulent conjunctivitis, arthralgia and malaise stand out. For details, check the section dedicated to diagnosis of ZIKV infection.

For the laboratory diagnosis of ZIKV infection, the clinical manifestations of the pregnant women increase the 
probability that plasma or serum RT-PCR can detect viral RNA. ${ }^{73}$ As already mentioned, this test has high sensitivity and specificity rates up to the fifth day after the appearance of the rash.

For pregnant women with ZIKV infection, it is necessary to search for other diseases that may cause rashes and microcephaly, which requires the organization of a specific flow to reduce their anxiety, avoid wasting time and optimize costs. In view of the limited access to molecular biology techniques for all these pregnant women, it is advisable to simultaneously investigate some of the diseases that may cause rashes by means of common serological tests, rapid tests or by looking for specific markers (DENV, CHIKV, syphilis, rubella, toxoplasmosis, cytomegalovirus, and herpes).

\section{Treatment of Pregnant Women with ZIKV Infection}

To date, there is no description of any specific medication to combat or control ZIKV infection. The use of antipyretics and common analgesics (dipyrone and acetaminophen) is recommended to control the febrile and painful symptoms. Until dengue infection is discarded, the use of acetylsalicylic acid or other non-steroidal anti-inflammatory drugs (NSAIDs) should be avoided. ${ }^{11,74}$ Water intake is encouraged to avoid dehydration. In general, ZIKV infection does not require hospitalization, and its complication rate is low. However, when complications occur, they are serious, such as meningoencephalitis and Guillain-Barré syndrome. ${ }^{25,40}$

Pregnant women with severe pruritus require a symptomatic treatment. Hydroxyzine may be used, with the drawback of drowsiness. If a non-sedative treatment is necessary, loratadine or cetirizine may be used. ${ }^{76,77}$ Cases demanding the use of topical or even systemic corticosteroids are rare.

Aiming to avoid the spread of infection by ZIKV, the care should continue to prevent patients from being bitten again, potentially infecting new vectors. This measure helps to control the spread of ZIKV infection and prevents pregnant women from being victims of other arboviruses. If for some reason hospitalization of the pregnant woman with ZIKV infection is necessary up to the seventh day of the onset of the symptoms, all measures should be taken to avoid the spread of the virus in the hospital environment. Among such measures, the hospitalization unit should have screen protection in the windows, the patients' skin should be protected, and repellents should be applied on the unprotected areas of the skin.

Given the lack of knowledge about the dimensions of the risk of sexual transmission of the ZIKV from women to their partners, for safety reasons, there should be sexual abstinence or consistent use of condoms for at least 60 days. This topic must be reviewed in the future..$^{30-32}$

\section{Prenatal Care of Pregnant Women with ZIKV Infection}

It is noteworthy that the fetal damage credited to ZIKV infection so far depends on which gestational age occurred the infection. It seems that the earlier the contact with the virus, the more severe is the fetal damage. ${ }^{54}$ For this reason, information about the last menstrual period is key. In lack of it, ultrasound documentation of the gestational age is imperative. In the prenatal follow-up of pregnant women diagnosed with ZIKV infection, there is no biochemical laboratory specificity.

When defining the place of follow-up for the pregnant women with ZIKV infection, we have learned the lesson that the place of care provision depends on the possibilities of the hierarchical flow of health in the particular communities where they live. If there is the possibility of making referrals to greater-complexity care, this should be done preferably to the tertiary level. If there is no such possibility, the follow-up can be performed in the unit of care, but with the guarantee of monthly ultrasound examinations until birth to identify or eliminate any type of fetal damage. Diagnosing any fetal abnormality requires referrals to greater-complexity services according to the usual flow in a particular community for cases of fetal changes in the central nervous system, notably microcephaly. ${ }^{10}$ Prenatal return consultations will follow the usual routine for risk pregnancies if no change is diagnosed.

To date, there is no information contraindicating vaginal delivery, even if the mother is in the acute phase of the ZIKV infection. In the puerperal period, there is no different measure, and natural breastfeeding is allowed. In case of acute infection, care should be taken to prevent the patient from being bitten in the hospital setting, putting other patients in the same environment at risk. It is important to reinforce that the hospitalization unit of these patients should be equipped with screen protection in windows, the patients' skin should be protected with appropriate clothing, and repellents must be applied on the unprotected areas of the skin.

\section{Prenatal Care of Pregnant Women whose Fetus are Diagnosed with Microcephaly}

In another moment, the diagnosis of fetal changes in ultrasound examinations will also be used to include pregnant women in the care line for pregnant women diagnosed with ZIKV infection (confirmed or not). This is independent from the presence or information of a recent or past rash. The first step is the confirmation of the diagnosis of microcephaly. After confirmation, care should be provided in a high-complexity environment, because microcephaly has perinatal prognoses that qualify the gestation as a gestation of high perinatal risk. If there are conditions to access genetic services, the evaluation of the case by a professional in this area is of great value, as this will expedite the flow for the differential diagnosis of microcephaly of chromosomal or genetic causes. $^{10}$

The growth curve parameters of the Intergrowth 21 project ${ }^{49,65}$ and of the $\mathrm{WHO}^{46}$ will be used to confirm the diagnosis of microcephaly. For this purpose, every fetus or neonate with a CP measurement of 2 SDs bellow the mean (considering gestational age and sex) will be considered as 
having microcephaly. For neonates above 37 weeks, the WHO curve (CP measurement of 2 SDs below the mean) will be used, also considering sex and gestational age.

In the prenatal care of pregnant women whose fetuses were diagnosed with microcephaly, the existing flows and referrals for services that serve pregnant women demanding greater complexity of resources, aiming at the birth and follow-up of the newborn, will be used. During the prenatal care of mothers with fetuses with microcephaly caused by the ZIKV, the protocols of each service, with no differences or specificities, will be followed. In general, the concern in these cases is with fetal vitality. However, specific institutional efforts should be directed to provide psychotherapeutic support for these mothers, and extend it to the families directly involved with this health problem. Upon confirming social vulnerability, social workers should also be involved. ${ }^{10}$

\section{Childbirth of Pregnant Women Exposed to ZIKV Infection}

To date, there is no information on any particularity regarding the delivery of pregnant women with ZIKV infection. Until the available knowledge indicates a different intervention, vaginal delivery will be advised. In cases of fetal microcephaly, there is no particularity in the delivery, regardless of the etiology. However, in the presence of microcephaly and depending on the severity of the process, it is necessary to use strategies for deliveries considered as highrisk, which require experienced health personnel and electronic resources for fetal vitality. Likewise, neonatal care should be performed by a professional trained in the care of high-risk neonates. ${ }^{10}$

The diagnosis of microcephaly during prenatal care allows the referral of pregnant women to reference services. However, the delivery of a child with undiagnosed microcephaly will possibly be performed in a typical maternity setting, eventually causing some discomfort and difficulties with the early stimulation of the newborn. ${ }^{78}$

For the diagnosis of microcephaly after birth, the choice among reference standards was for the Intergrowth 21 postnatal curves designed to evaluate preterm and fullterm infants in the postnatal period. ${ }^{49}$ The WHO curve can also be used for full term children. ${ }^{46}$

\section{Puerperal Period of Pregnant Women Exposed to ZIKV}

There is no particularity about the puerperal period of women who have been or are in the period of infection by the ZIKV. Although the ZIKV is eliminated through the breast milk, there is no contraindication to breastfeeding. Natural breastfeeding is objectively advised, especially in cases of microcephaly, as these neonates will surely need greater nutritional care. Psychotherapeutic support is also strongly advised, because it plays an important role in this phase. ${ }^{10}$ Another important detail is the reassurance for puerperal women regarding the availability of basic care services, specialized rehabilitation services, tests, diagnostic services, hospital services, as well as orthoses and prostheses in case their child needs it. This is undoubtedly the most vulnerable point in all attempts to organize a care program for the mother/child/family affected by the ZIKV. This is the biggest challenge against the vertical transmission of the ZIKV for health institutions in Brazil, since adequate care for the young children suffering from this epidemic requires much more than our health system is prepared to offer. These children have organic, cognitive and psychomotor disorders that demand special care programs, ${ }^{78}$ making scarcer the resources that were already insufficient to meet the previous health demands in the country. ${ }^{55}$

\section{Acknowledgements}

This review is part of the Guidelines and Recommendations of the Brazilian Federation of Gynecology and Obstetrics Associations - FEBRASGO, and was prepared by the National Provisional Specialized Commission for the Study of the Zika Virus, Pregnancy and Microcephaly.

\section{References}

1 Brasil. Ministério da Saúde do Brasil. Ministério da Saúde confirma relação entre vírus Zika e microcefalia [Internet]. Brasília (DF): Ministério da Saúde; 2015; [cited in Dec 22, 2015]. Available at: http://portalsaude.saude.gov.br/index.php/cidadao/principal/ agencia-saude/21014-ministerio-da-saude-confirma-relacaoentre-virus-zika-e-microcefalia

2 European Centre for Disease Prevention and Control (ECDC). Rapid risk assessment: Microcephaly in Brazil potentially linked to the Zika virus epidemic, 2015. Stockholm: ECDC; 2015

3 Mlakar J, Korva M, Tul N, et al. Zika virus associated with microcephaly. N Engl J Med 2016;374(10):951-958

4 Centro de Operações de Emergências em Saúde Pública Sobre Microcefalias (COESP). Informe Epidemiológico $\mathrm{N}^{\circ} 23$. Semana Epidemiológica 16/2016 (17/04 a 23/04/2016). Monitoramento dos casos de microcefalia no Brasil [Internet]. [citado Apr 24, 2016]. Available at: http://portalsaude.saude.gov.br/images/pdf/ 2016/abril/27/COES-Microcefalias-Informe-Epidemiol-gico23-SE-16-2016-25abril2016-20h07.pdf

5 Rasmussen SA, Jamieson DJ, Honein MA, Petersen LR. Zika Virus and Birth defects-Reviewing the Evidence for Causality. N Engl J Med 2016;374(20):1981-1987

6 Ministério da Saúde (MS) Secretaria de Vigilância em Saúde, Departamento de Vigilância das Doenças Transmissíveis. Protocolo de Vigilância e Resposta à Ocorrência de Microcefalia Relacionada à Infecção Pelo Vírus Zika. Ministério da Saúde, Secretaria de Vigilância em Saúde, Departamento de Vigilância das Doenças Transmissíveis. Brasília (DF); Ministério da Saúde: $1-71,2015 b$

7 São Paulo State Government. Secretaria de Estado da Saúde, Coordenadoria de Controle de Doenças Centro de Vigilância Epidemiológica, Instituto Adolfo Lutz. Vigilância das microcefalias relacionadas à infecção pelo vírus Zika. São Paulo; SESP-SP: 1-13, 2015. [Informe Técnico $N^{\circ} 1$ de 14/12/2015]

8 Tetro JA. Zika and microcephaly: causation, correlation, or coincidence? Microbes Infect 2016;18(03):167-168

9 Schuler-Faccini L, Ribeiro EM, Feitosa IM, et al; Brazilian Medical Genetics Society-Zika Embryopathy Task Force. Brazilian Medical Genetics Society-Zika Embryopathy Task Force. Possible association between Zika virus infection and microcephaly - Brazil, 2015. MMWR Morb Mortal Wkly Rep 2016;65(03):59-62 
10 Duarte G. Infecção pelo vírus zika durante a gravidez. Femina 2016;44:26-48

11 Brasil. Ministério da Saúde. Secretaria de Vigilância em Saúde, Departamento de Vigilância das Doenças Transmissíveis. Protocolo de vigilância e resposta à ocorrência de microcefalia e/ou alterações do sistema nervoso central (SNC). Versão 2. Brasília (DF): Ministério da Saúde; 2016. p.1-55

12 São Paulo State Government. Secretaria de Estado da Saúde. Centro de Vigilância Epidemiológica da SESP-SP. Protocolo de vigilância para gestantes com exantema. São Paulo: Secretaria de Estado da Saúde; 2016

13 Olson CK, Iwamoto M, Perkins KM, et al. Preventing transmission of zika virus in labor and delivery settings through implementation of standard precautions - United States, 2016. MMWR Morb Mortal Wkly Rep 2016;65(11):290-292

14 Centers for Disease Control and Prevention (CDC). Zika virus transmission [Internet]. [cited 2015 Dec 18]. Available from: http://www.cdc.gov/zika/transmission/index.html

15 World Health Organization (WHO). Pregnancy management in the context of Zika virus. Interim guidance uptodate. Geneva: WHO; 2016 WHO/ZIKV/MOC/16.2; page 1-7

16 Duarte G. Cartilha sobre a infecção pelo vírus Zika para orientação das gestantes. Texto elaborado pela Comissão Nacional Especializada Provisória Zika Vírus, Gravidez e Microcefalia. Cartilha sobre a infecção pelo vírus Zika para orientação das gestantes [Internet]. [cited $2017 \mathrm{Fev} 18$ ]. Available at: http://www.febrasgo. org.br/site/wp-content/uploads/2016/02/Cartilha-sobre-a-infeccao-pelo-virus-Zika-para-orientacao-das-gestantes.pdf

17 Kuno G, Chang GJ, Tsuchiya KR, Karabatsos N, Cropp CB. Phylogeny of the genus Flavivirus. J Virol 1998;72(01):73-83

18 Klema VJ, Padmanabhan R, Choi KH. Flaviviral Replication Complex: Coordination between RNA Synthesis and 5'-RNA Capping. Viruses 2015;7(08):4640-4656

19 Dick GW, Kitchen SF, Haddow AJ. Zika virus. I. Isolations and serological specificity. Trans R Soc Trop Med Hyg 1952;46(05): 509-520

20 Imperato PJ. The convergence of a virus, mosquitoes, and human travel in globalizing the zika epidemic. J Community Health 2016; 41(03):674-679

21 Enfissi A, Codrington J, Roosblad J, Kazanji M, Rousset D. Zika virus genome from the Americas. Lancet 2016;387(10015):227-228

22 Faria NR, Azevedo RdoS, Kraemer MU, et al. Zika virus in the Americas: Early epidemiological and genetic findings. Science 2016;352(6283):345-349

23 Naccache SN, Thézé J, Sardi SI, et al. Distinct zika virus lineage in Salvador, Bahia, Brazil. Emerg Infect Dis 2016;22(10):1788-1792

24 Pan American Health Organization (PAHO). Alerta Epidemiológica-Síndrome neurológico, anomalías congénitas e infección por virus Zika. Implicaciones para la salud pública en las Américas [Internet]. Washington: Pan American Health Organization; 2015. [cited 2016 Nov 26]. Available at: http://www.paho.org/ hq/index.php?option=com_docman\&task=doc_view\&Itemid=270\&gid=32404\&lang=es

25 Kleber de Oliveira W, Cortez-Escalante J, De Oliveira WT, et al. Increase in Reported Prevalence of Microcephaly in Infants Born to Women Living in Areas with Confirmed Zika Virus Transmission During the First Trimester of Pregnancy-Brazil, 2015. MMWR Morb Mortal Wkly Rep 2016;65(09):242-247

26 Musso D, Cao-Lormeau VM, Gubler DJ.Zika virus: following the path of dengue and chikungunya? Lancet 2015;386(9990):243-244

27 França GV, Schuler-Faccini L, Oliveira WK, et al. Congenital Zika virus syndrome in Brazil: a case series of the first 1501 livebirths with complete investigation. Lancet 2016;388(10047):891-897

28 Miranda-Filho DdeB, Martelli CM, Ximenes RA, et al. Initial Description of the Presumed Congenital Zika Syndrome. Am J Public Health 2016;106(04):598-600

29 de Paula Freitas B, de Oliveira Dias JR, Prazeres J, et al. Ocular Findings in Infants With Microcephaly Associated With Presumed
Zika Virus Congenital Infection in Salvador, Brazil. JAMA Ophthalmol 2016;134(05):529-535

30 Oster AM, Russell K, Stryker JE, et al. Update: Interim Guidance for Prevention of Sexual Transmission of Zika Virus-United States, 2016. MMWR Morb Mortal Wkly Rep 2016;65(12): 323-325

31 Petersen EE, Meaney-Delman D, Neblett-Fanfair R, et al. Update: Interim guidance for preconception counseling and prevention of sexual transmission of zika virus for persons with possible zika virus exposure - United States, September 2016. MMWR Morb Mortal Wkly Rep 2016;65(39):1077-1081

32 World Health Organization (WHO). Prevention of sexual transmission of Zika virus. Interim guidance update. 2016; WHO/ZIKV/ MOC/16.1 Rev.3, page: 1-5. [cited 2017 Jan 8]. Available from: http://apps.who.int/iris/bitstream/10665/204421/1/WHO_ZIKV_MOC_16.1_eng.pdf?ua=1

33 Grischott F, Puhan M, Hatz C, Schlagenhauf P. Non-vector-borne transmission of Zika virus: A systematic review. Travel Med Infect Dis 2016;14(04):313-330

34 Nogueira ML, Estofolete CF, Terzian AC, et al. Zika virus infection and solid organ transplantation: A new challenge. Am J Transplant 2017;17(03):791-795

35 Musso D, Nhan T, Robin E, et al. Potential for Zika virus transmission through blood transfusion demonstrated during an outbreak in French Polynesia, November 2013 to February 2014. Euro Surveill 2014;19(14):20761

36 Cunha MS, Esposito DL, Rocco IM, et al. First complete genome sequence of Zika virus (Flaviviridae, Flavivirus) from an autochthonous transmission in Brazil. Genome Announc 2016;4(02): 16-32

37 Cardoso CW, Paploski IA, Kikuti M, et al. Outbreak of exanthematous illness associated with Zika, Chikungunya, and Dengue viruses, Salvador, Brazil. Emerg Infect Dis 2015;21(12): 2274-2276

38 Duffy MR, Chen TH, Hancock WT, et al. Zika virus outbreak on Yap Island, Federated States of Micronesia. N Engl J Med 2009; 360(24):2536-2543

39 Piersen TC, Diamond MS. Flaviviruses. In: Knipe DM, Howley PM, eds. Fields Virology. Philadelphia, PA: Wolters Kluver/Lippincott/ Williams \& Wilkins; 2013. p. 747-95

40 Centers for Disease Control and Prevention (CDC). Interim guidance for zika virus testing of urine - United States, 2016. MMWR Morb Mortal Wkly Rep 2016;65(18):474

41 Centers for Disease Control and Prevention (CDC). Trioplex Realtime RT-PCR Assay. For use under an emergency use authorization only [Internet]. [cited 2016 Nov 22]. Available from: http:// www.fda.gov/downloads/MedicalDevices/Safety/EmergencySituations/UCM491592.pdf

42 Centers for Disease Control and Prevention (CDC). Diagnostic testing [Internet]. [cited 2016 Nov 22]. Available from http:// www.cdc.gov/zika/hc-providers/diagnostic.html

43 Oehler E, Watrin L, Larre P, et al. Zika virus infection complicated by Guillain-Barre syndrome-case report, French Polynesia, December 2013. Euro Surveill 2014;19(09):20720

44 Zara AL, Santos SM, Fernandes-Oliveira ES, Carvalho RG, Coelho GE. [Aedes aegypti control strategies: a review]. Epidemiol Serv Saude 2016;25(02):391-404

45 Centro de Operações de Emergências em Saúde Pública sobre Microcefalias (COES - Microcefalias, 2016) [Internet]. [cited 2017 Jan 19]. Available from: http://combateaedes.saude.gov. br/images/pdf/Informe-Epidemiologico-n57-SE-52_201609jan2017.pdf

46 World Health Organization (WHO/OMS). WHO Child Growth Standards: Growth velocity based on weight, length and head circumference. Methods and development. Geneva: World Health Organization. 2009:1-242 [Internet]. [cited 2017 Jan 12]. Available from: http://www.who.int/childgrowth/standards/en/ 
47 World Health Organization (WHO), Centers for Disease Control and Prevention (CDC), International Clearinghouse for Birth Defects Surveillance and Research (ICBDSR). Birth Defects Surveillance: A Manual for Programme Managers. Geneva: World Health Organization; 2014. p.1-116

48 Papageorghiou AT, Ohuma EO, Altman DG, et al; International Fetal and Newborn Growth Consortium for the 21st Century (INTERGROWTH-21st). International standards for fetal growth based on serial ultrasound measurements: the Fetal Growth Longitudinal Study of the INTERGROWTH-21st Project. Lancet 2014;384(9946):869-879

49 Intergrowth-21st. Intergrowth-21st Fetal Growth Standards. Accessed in Apr 14, 2016. Available at http://intergrowth21. ndog.ox.ac.uk/

50 World Health Organization (WHO). Assessment of infants with microcephaly in the context of Zika virus. Interim guidance. Geneva: WHO; 2016. WHO/ZIKV/MOC/16.3; Rev. 1, page 1-2

51 Papageorghiou AT, Thilaganathan B, Bilardo CM, et al. ISUOG Interim Guidance on ultrasound for Zika virus infection in pregnancy: information for healthcare professionals. Ultrasound Obstet Gynecol 2016;47(04):530-532

52 Ashwal S, Michelson D, Plawner L, Dobyns WB; Quality Standards Subcommittee of the American Academy of Neurology and the Practice Committee of the Child Neurology Society. Practice parameter: Evaluation of the child with microcephaly (an evidencebased review): report of the Quality Standards Subcommittee of the American Academy of Neurology and the Practice Committee of the Child Neurology Society. Neurology 2009;73(11):887-897

53 Qian X, Nguyen HN, Song MM, et al. Brain-Region-Specific Organoids Using Mini-bioreactors for Modeling ZIKV Exposure. Cell 2016;165(05):1238-1254

54 Honein MA, Dawson AL, Petersen EE, et al; US Zika Pregnancy Registry Collaboration. Birth defects among fetuses and infants of US women with evidence of possible zika virus infection during pregnancy. JAMA 2017;317(01):59-68

55 Duarte G. Challenges of Zika Virus Infection in Pregnant Women. Rev Bras Ginecol Obstet 2016;38(06):263-265

56 Oliveira Melo AS, Malinger G, Ximenes R, Szejnfeld PO, Alves Sampaio S, Bispo de Filippis AM. Zika virus intrauterine infection causes fetal brain abnormality and microcephaly: tip of the iceberg? Ultrasound Obstet Gynecol 2016;47(01):6-7

57 Suy A, Sulleiro E, Rodó C, et al. Prolonged zika virus viremia during pregnancy. N Engl J Med 2016;375(26):2611-2613

58 Abuelo D. Microcephaly syndromes. Semin Pediatr Neurol 2007; 14(03):118-127

59 Bailão LA, Osborne NG, Rizzi MC, Bonilla-Musoles F, Duarte G, Bailão TC. Ultrasound markers of fetal infection part 1: viral infections. Ultrasound Q 2005;21(04):295-308

60 Papageorghiou AT, Kemp B, Stones W, et al; International Fetal and Newborn Growth Consortium for the 21st Century (INTERGROWTH-21st). Ultrasound-based gestational-age estimation in late pregnancy. Ultrasound Obstet Gynecol 2016;48(06): 719-726

61 Leibovitz Z, Daniel-Spiegel E, Malinger G, et al. Prediction of microcephaly at birth using three reference ranges for fetal head circumference: can we improve prenatal diagnosis? Ultrasound Obstet Gynecol 2016;47(05):586-592

62 Fenton TR, Kim JH. A systematic review and meta-analysis to revise the Fenton growth chart for preterm infants. BMC Pediatr 2013;13:59
63 Chervenak FA, Jeanty P, Cantraine F, et al. The diagnosis of fetal microcephaly. Am J Obstet Gynecol 1984;149(05):512-517

64 Chervenak FA, Rosenberg J, Brightman RC, Chitkara U, Jeanty P. A prospective study of the accuracy of ultrasound in predicting fetal microcephaly. Obstet Gynecol 1987;69(06):908-910

65 Villar J, Giuliani F, Bhutta ZA, et al; International Fetal and Newborn Growth Consortium for the 21(st) Century (INTERGROWTH21(st)). Postnatal growth standards for preterm infants: the Preterm Postnatal Follow-up Study of the INTERGROWTH-21 (st) Project. Lancet Glob Health 2015;3(11):e681-e691

66 Petersen EE, Polen KN, Meaney-Delman D, et al. Update: Interim Guidance for Health Care Providers Caring for Women of Reproductive Age with Possible Zika Virus Exposure - United States, 2016. MMWR Morb Mortal Wkly Rep 2016;65(12): 315-322

67 Atkinson B, Thorburn F, Petridou C, et al. Presence and persistence of zika virus RNA in semen, United Kingdom, 2016. Emerg Infect Dis 2017;23(04):611-615; [ Epub ahead of print] DOI: 10.3201/ eid2304.161692

68 McCarthy M. Couples at risk from exposure to Zika virus should consider delaying pregnancy, says CDC. BMJ 2016;352:i1813

69 Fuwa K, Hayakawa S. Mechanisms and possible controls of the in utero Zika virus infection: Where is the Holy Grail? Am J Reprod Immunol 2017;77(02) Epub2016Dec14. Doi: 10.1111/ aji.12605

70 Mansuy JM, Suberbielle E, Chapuy-Regaud S, et al. Zika virus in semen and spermatozoa. Lancet Infect Dis 2016;16(10): 1106-1107

71 Barzon L, Pacenti M, Franchin E, et al. Infection dynamics in a traveller with persistent shedding of Zika virus RNA in semen for six months after returning from Haiti to Italy, January 2016. Euro Surveill 2016;21(32):30316

72 Agência Nacional de Vigilância Sanitária (Anvisa), Ministério da Saúde. Funcionamento dos Bancos de Células e Tecidos Germinativos. Resolução DC/Anvisa, $\mathrm{n}^{\circ} 72$ de 30/03/2016, Brasília: Anvisa, 2016 [Internet]. Publicada no DOU, $n^{\circ}$ 62, de 01/04/16, Seção 1: p.103 [cited 2017 Fev 19]. Disponível no ftp://ftp.saude. sp.gov.br/ftpsessp/bibliote/informe_eletronico/2016/iels.abr.16/ Iels60/U_RS-MS-ANVISA-RDC-72_300316.pdf

73 Oduyebo T, Petersen EE, Rasmussen SA, et al. Update: Interim Guidelines for Health Care Providers Caring for Pregnant Women and Women of Reproductive Age with Possible Zika Virus Exposure - United States, 2016. MMWR Morb Mortal Wkly Rep 2016;65(05):122-127

74 Citil Dogan A, Wayne S, Bauer S, et al. The Zika virus and pregnancy: evidence, management, and prevention. J Matern Fetal Neonatal Med 2017;30(04):386-396

75 Torres JR, Falleiros-Arlant LH, Dueñas L, Pleitez-Navarrete J, Salgado DM, Castillo JB. Congenital and perinatal complications of chikungunya fever: a Latin American experience. Int J Infect Dis 2016;51:85-88

76 Petersen EE, Staples JE, Meaney-Delman D, et al. Interim Guidelines for Pregnant Women During a Zika Virus Outbreak - United States, 2016. MMWR Morb Mortal Wkly Rep 2016;65(02):30-33

77 Ambros-Rudolph CM. Dermatoses of pregnancy - clues to diagnosis, fetal risk and therapy. Ann Dermatol 2011;23(03):265-275

78 Teixeira MG, Costa MdaC, de Oliveira WK, Nunes ML, Rodrigues LC. The Epidemic of Zika Virus-Related Microcephaly in Brazil: Detection, Control, Etiology, and Future Scenarios. Am J Public Health 2016;106(04):601-605 